This PDF is a selection from an out-of-print volume from the National Bureau of Economic Research

Volume Title: Postwar Market for State and Local Government Securities

Volume Author/Editor: Roland Robinson

Volume Publisher: Princeton University Press

Volume ISBN: 0-870-14103-1

Volume URL: http://www.nber.org/books/robi60-1

Publication Date: 1960

Chapter Title: Appendix B: Results of Conventional (Nonaccrual) Method of Computing Interest Cost Which Prevails in Competitive Bidding for State and Local Government Issues

Chapter Author: Roland Robinson

Chapter URL: http://www.nber.org/chapters/c2446

Chapter pages in book: (p. 217 - 223) 


\section{Results of Conventional (Nonaccrual) Method of Computing Interest Cost Which Prevails in Competitive Bidding for State and Local Government Issues}

INTEREST cost computations are all based in some measure on rules or conventions. No one method can be considered categorically "right" and all other methods wrong. But in practice it is widely agreed that the "present value" method of computing the value of bonds as it is used in preparing bond tables presents a close approximation to what is normally thought of as interest cost or interest expense. ${ }^{1}$ It is true, of course, that even this method has some elements of approximation, the greatest one being introduced by the existence of a term structure of interest rates. For example, when a bond with its attached coupons is discounted to its present value, the calculated yield assumes the same rate for discounting each maturity. But this assumption does some violence to the facts of the market; sloping yield curves often prevail. However, for most purposes this flaw is not important so long as both parties to a transaction in securities understand this fact.

The computation of interest cost made in picking winning bids for virtually all state and local government bond issues in the United States, however, is not based on a "present value" type of computation; it is based on an older formula. This formula will be demonstrated in detail later in this appendix, but it amounts to a simple ratio of coupons to principal weighted by the period the principal is outstanding.

Because such a large proportion of state and local government securities are in serial form, the persistence of this older form of computation is understandable. Other rules would make for more complex calculations. But its existence is largely an anachronism which often tends to focus attention on the wrong factors. Later in this appendix we shall argue this point at greater length. At this juncture it would be better to illustrate this method of com-

1 The "present value" form of calculation is also sometimes referred to as the "accrual" or "annuity" method of computing bond values. 
putation and then to study some of its variations in practice. A hypothetical illustration has been devised and then elaborated to help in the exposition of this problem (see Table B-I).

\section{TABLE B-I}

Hypothetical Illustration of Conventional (Nonaccrual) Method of Computing Interest Cost Prevailing in State and Local Government Borrowing

Part 1. Assume $\$ 10,000$ borrowed in 1956 to mature in equal annual instalments of $\$ 1,000$ over the next ten years and assume coupons shown in Column 5

\begin{tabular}{lccccc}
\hline \hline Maturity & $\begin{array}{c}\text { Years to } \\
\text { Maturity } \\
\text { (Assumed) }\end{array}$ & $\begin{array}{c}\text { Principal } \\
\text { Maturing } \\
\text { EachYear }\end{array}$ & $\begin{array}{c}\text { Principal } \\
\text { Outstanding } \\
\text { for One Year } \\
\text { (Col. } 2 \times \text { col. } 3)\end{array}$ & $\begin{array}{c}\text { Coupon } \\
\text { (Assumed) }\end{array}$ & $\begin{array}{c}\text { Interest } \\
\text { Cost }\end{array}$ \\
\hline 1957 & 1 & $\$ 1,000$ & $\$ 1,000$ & 4 & 40 \\
1958 & 2 & 1,000 & 2,000 & 4 & 80 \\
1959 & 3 & 1,000 & 3,000 & 4 & 120 \\
1960 & 4 & 1,000 & 4,000 & $21 / 4$ & 90 \\
1961 & 5 & 1,000 & 5,000 & $21 / 4$ & 112.50 \\
1962 & 6 & 1,000 & 6,000 & $21 / 2$ & 150 \\
1963 & 7 & 1,000 & 7,000 & $21 / 2$ & 175 \\
1964 & 8 & 1,000 & 8,000 & $21 / 2$ & 200 \\
1965 & 9 & 1,000 & 9,000 & $21 / 2$ & 225 \\
1966 & 10 & 1,000 & 10,000 & $21 / 2$ & 250 \\
Total & & & $\$ 55,000$ & & $1,442.5$ \\
Interest cost computation: $\$ 1,442.50$ & $\$ 55,000=2.6227$ per cent. & \\
\hline
\end{tabular}

Part 1 of the illustration sets up the basic circumstances that might prevail in a very simple and uncomplicated state or local government financing. To ease the computations, small amounts have been used and all figures are rounded to the extent possible. The only departure from utter simplicity is that involved in the coupon structure assumed. In this case, we have used three different coupon rates. As was developed in Chapter 4 above, such a coupon system would not be far from those which often prevail: high for the first few maturities, i.e., 4 per cent; dropping back to $21 / 4$ per cent in the middle and then up a bit again to $21 / 2$ per cent in the later maturities. The so-called interest cost is simply 


\section{APPENDIX:B}

the number of dollars that will be paid out as coupons. The "principal outstanding for one year" is each year's serial obligation, multiplied by the number of years it will be outstanding. The total of "principal outstanding for one year". is the equivalent of a single amount if it were at interest for one year. ${ }^{2}$ The average rate of interest cost is then simply the interest cost in dollars divided by the total "principal outstanding for one year." If the bidder offers a premium, it is deducted from the dollar amount of coupons before computing the rate of interest cost. This will be illustrated in later parts.

It should be noted that this form of computation makes no distinction between a dollar of interest paid during the early years of the obligation and a dollar of interest paid in the late years near final maturity. According to a present value basis of computation, of course, the earlier dollar is worth more and correspondingly "costs" more than a later dollar. This lies back of much of the complexity in the coupon structures of many state and local government issues. Most of the sale announcements allow bidders to name the coupon or coupons to be placed in the proposed issue. Some invitations allow the bidders to name only one coupon rate; others permit varying "split coupon" arrangements. Usually only one coupon can be named for each maturity, but in a few cases more than one coupon rate for a given maturity is allowed. While the nonaccrual interest cost computation formula makes no distinction between early coupon dollars and later ones, the market does. In all investment markets, including that for state and local government securities, the conventions of computation are on a "present value" basis. Underwriters, therefore, can realize more from the sale of a given dollar volume of coupons on early maturities (where the discount to present value of the coupon is small) than for a similar volume of coupons on later maturities. Accordingly, there is a general disposition for the underwriters to put high coupons on early issues and lower ones on the longer maturities. The more this is done, the lower the computed interest cost ac-

2 If the amounts in each maturity of an issue are equal and the period to maturity is in whole number digits, then the simple sum of digits formula could be used; i.e., $\frac{n(n+1)}{2}$ in this case $\frac{10(10+1)}{2}=55$ times $\$ 1,000=\$ 55,000$. In practice these assumptions are quite often not true so the more direct even if more laborious calculation is usually performed. 
cording to this archaic formula of state and municipal bidding. It is not a real saving to the borrowing governments, only a fictional one. The trouble is that this fiction has even fooled some members of the investment banking community. They speak of spending tedious hours in the price meetings held by syndicates working out coupon structures that will "save the borrowing government's money." Nothing is being saved, of course, and the market is only being made that much more complex.

This is shown in Part 2 of the hypothetical illustration (see Table B-2). For the purpose of this part one added assumption has been made: that of an up-sweeping yield "curve," a straight line in this case. Three different hypothetical cases are presented. In the first

\section{TABLE B-2}

Hypothetical Illustration

Part 2. Same assumptions as in Part 1 , with added assumptions about prevailing yields and different coupon assumptions

\begin{tabular}{|c|c|c|c|c|c|c|c|}
\hline \multirow[b]{2}{*}{ Maturity } & \multirow{2}{*}{$\begin{array}{c}\text { Prevailing } \\
\text { Yield } \\
\text { (Assumed) }\end{array}$} & \multirow{2}{*}{$\begin{array}{c}\text { CASE } 1 \\
\text { Coupon- } \\
\text { Yield } \\
\text { Interest } \\
\text { Cost }\end{array}$} & $2.6 \mathrm{Per} \mathrm{Ce}^{\mathrm{CA}}$ & $\begin{array}{l}\text { SE } 2 \\
\text { ent Coupon }\end{array}$ & \multicolumn{3}{|c|}{ CASE 3} \\
\hline & & & $\begin{array}{c}\text { Interest } \\
\text { Cost }\end{array}$ & Price & $\begin{array}{c}\text { Coupon } \\
\text { (per cent) }\end{array}$ & $\begin{array}{c}\text { Interest } \\
\text { Cost }\end{array}$ & Price \\
\hline 1957 & 2.00 & 20 & 26 & $1,005.90$ & 108.0 & 1,080 & $2,039.20$ \\
\hline 1958 & 2.10 & 42 & 52 & $1,009.70$ & 0.5 & 10 & 968.80 \\
\hline 1959 & 2.20 & 66 & 78 & $1,011.60$ & 0.5 & 15 & 950.90 \\
\hline 1960 & 2.30 & 92 & 104 & $1,011.40$ & 0.5 & 20 & 931.60 \\
\hline 1961 & 2.40 & 120 & 130 & $1,009.40$ & 0.5 & 25 & 911.00 \\
\hline 1962 & 2.50 & 150 & 156 & $1,005.50$ & 0.5 & 30 & 889.20 \\
\hline 1963 & 2.60 & 182 & 182 & $1,000.00$ & 0.5 & 35 & 866.40 \\
\hline 1964 & 2.70 & 216 & 208 & 992.80 & 0.5 & 40 & 842.70 \\
\hline 1965 & 2.80 & 252 & 234 & 984.20 & 0.5 & 45 & 818.10 \\
\hline 1966 & 2.90 & 290 & 260 & 974.10 & 0.5 & 50 & 793.00 \\
\hline Total & & $\overline{1,430}$ & $\overline{1,430}$ & $\overline{10,004 . \overline{60}}$ & & $\overline{1,350}$ & $\overline{10,010.90}$ \\
\hline
\end{tabular}

Interest cost computations:

Case 1: $\$ 1,430 \div \$ 55,000=2.6$ per cent (equivalent to "present value" cost).

Case 2: $\left(\$ 1,430-\$ 4.60^{*}\right) \div \$ 55,000=2.5916$ per cent.

Case 3: $\left(\$ 1,350-\$ 10.90^{*}\right) \div \$ 55,000=2.4347$ per cent.

- Premium.

Cols. 5 and 9 were taken from yield tables using the assumed coupons of the yields applicable in each case. 
one a different coupon is put on each maturity and the coupon is made exactly identical to the assumed yield. In other words, these bonds should all sell exactly at par. This should result in as near a true interest cost at present value as any case we present here. In the second case, just one coupon has been attached to the issue, the coupon which is the average interest cost for the entire issue according to the computations of case 1 . Here, the price which would be realized for each maturity of bond is shown in column 5 of part 2; the total for this column shows that the issue as a whole would sell for $\$ 4.60$ more than par. If this $\$ 4.60$ is deducted from the interest cost as figured in column 4 (which has the same total as column 3 but not the same amounts year-by-year), the resulting computation of interest cost by the conventional formula for awarding bids for state and local government bonds ends up slightly less than that shown in case 1 . In other words, with the assumption of an ascending yield curve, a single coupon gives a computed lower average interest cost than a coupon fitted exactly to the yields of the market which is presumably a sort of ideal case in which present value and interest cost both yield the same results.

But the extreme, and of course unreal, case would be that in which the coupon cost was moved into the first year as much as possible and as little as possible was allowed for later years. This grotesque illustration is case 3 . Here a coupon of $1 / 2$ of 1 per cent for the last nine maturities was assumed; the coupon of the first year was loaded to the point necessary to make the whole issue sell for more than par, which amount turned out to be the absurd coupon of 108 per cent per annum. When the computation of interest cost according to the conventional state and local government formula is made, the presumption of lower cost is striking; the margin is much more than that which usually separates the bids of competing buyers.

In practice, of course, the buyers of issues could never go as far as case 3 assumes. The buyers are usually underwriting groups who must sell the obligations to ultimate investors, and ultimate investors have an understandable reluctance for odd and extreme coupons. A security having a coupon of 108 per cent might be salable to a commercial bank with a sophisticated investment department and, what is more important, a sophisticated and understanding 
board of directors. But there are problems of an even greater character in selling low-coupon long-term bonds even at deep discounts. For one thing, as already pointed out in Chapter 6, only the initial purchaser of these..bonds can use the full yield for purposes of getting an exemption from income taxation; subsequent purchasers can use only the coupon. Thus these bonds are peculiarly unmarketable obligations.

But just the same, the effects of manipulated coupon structures on the computed interest cost is material; shrewd investment bankers with sharp pencils have found that it is worthwhile to go to the extra trouble involved in marketing these securities with special coupons; they can win bids by such devices. Much of the energy of the great houses which manage the syndicate accounts that bid for these securities is devoted to just this purpose.

In Part 3 of our hypothetical illustration, we attempt to introduce a note of reality into our computations (Table B-3). In the first place, the other computations assumed a market yield and any premium resulting from the "price" calculated in each case was deducted from the dollar value of the coupons or the interest cost in dollars in full. In other words, we were making no allowance for the margin of the investment banker. In cases 4 and 5 we drop this quite unreal assumption and allow a margin of one dollar a bond. For case 4 we assume a bidding group that can market some of the early maturities at a fairly high coupon, but otherwise they cannot find buyers unless they put on coupons that will "produce" prices not too far from par. The price (which multiplied by the dollar amount in each maturity is called the "production" in underwriting parlance) must yield a little margin over par since the bidding rules in most cases require a bid of par or better. and the group must also work out its own margin from the sale price of the obligations. For the purpose of this case we have assumed that the second bidding group (case 5) has somewhat more aggressive salesmen; they figure that they will be able to sell the early maturities at an even higher coupon than was estimated by the first group. But their real secret weapon is assumed to be an advance deal by which they can sell the one longest maturity at a $1 / 2$ of one per cent coupon. They have found one investor who will buy this long-term, deep-discount bond in spite of its dis- 


\section{TABLE B-3}

Hypothetical Illustration

Part 3. Same assumptions as in Parts 1 and 2, with still different coupon assumptions and with the further exception that underwriters bidding for issues are assumed to retain a profit of one dollar a bond

\begin{tabular}{|c|c|c|c|c|c|c|}
\hline \multirow[b]{2}{*}{ Maturities } & \multicolumn{3}{|c|}{ CASE 4} & \multicolumn{3}{|c|}{ CASE 5} \\
\hline & $\begin{array}{l}\text { Coupon } \\
\quad \text { SSame }\end{array}$ & $\begin{array}{l}\text { Interest } \\
\text { Cost } \\
\text { Part I) }\end{array}$ & $\begin{array}{c}\text { Price } \\
\text { ("produc- } \\
\text { tion") }\end{array}$ & Coupon & $\begin{array}{c}\text { Interest } \\
\text { Cost }\end{array}$ & $\begin{array}{c}\text { Price } \\
\text { ("produc- } \\
\text { tion") }\end{array}$ \\
\hline 1957 & 4 & 40 & $1,019.70$ & 5 & 50 & $1,029.50$ \\
\hline 1958 & 4 & 80 & $1,037.00$ & 5 & 100 & $1,056.50$ \\
\hline 1959 & 4 & 120 & $1,052.00$ & 5 & 150 & $1,080.90$ \\
\hline 1960 & $21 / 4$ & 90 & 998.10 & 5 & 200 & $1,102.60$ \\
\hline 1961 & $21 / 4$ & 112.5 & 993.00 & $21 / 2$ & 125 & $1,004.70$ \\
\hline 1962 & $21 / 2$ & 150 & $1,000.00$ & $21 / 2$ & 150 & $1,000.00$ \\
\hline 1963 & $21 / 2$ & 175 & 993.60 & $21 / 2$ & 175 & 993.60 \\
\hline 1964 & $21 / 2$ & 200 & 985.70 & $21 / 2$ & 200 & 985.70 \\
\hline 1965 & $21 / 2$ & 225 & 976.30 & $21 / 2$ & 225 & 976.30 \\
\hline 1966 & $21 / 2$ & 250 & 965.40 & $1 / 2$ & 50 & 793.00 \\
\hline Total & & $\overline{1,442.5}$ & $\overline{10,020.80}$ & & $\overline{1,425}$ & $\overline{10,022.80}$ \\
\hline
\end{tabular}

Interest cost computations:

Case 4: $\left(\$ 1,442.50-\$ 10.80^{*}\right) \div \$ 55,000=2.6031$ per cent.

Case 5: $\left(\$ 1,425-\$ 12.80^{*}\right) \div \$ 55,000=2.5676$ per cent.

- Prenium less underwriters' profit.

advañtages. ${ }^{3}$ The intervening coupon was doubtless arrived at during the price meeting of this bidding group at a level which was figured salable and which would "produce" a price above par for the whole issue. Using these assumptions, we find that the interest cost in case 5 is materially below that of case 4 .

${ }^{3}$ In practice they probably would have had to offer this one maturity at a yield considerably higher than the market for a more conventional issue. The low-coupon terminal maturities are usually not reoffered publicly, but underwriters report that the effective yield at which these special obligations are sold is usually from 40 to 60 basis points above a comparable maturity sold at par. 